\title{
Leptin, nutrition and reproduction: new insights
}

\author{
Vera Popovic $^{1}$, Felipe F. Casanueva ${ }^{2}$ \\ ${ }^{1}$ Institute of Endocrinology,Diabetes and Metabolic Diseases, University Clinical Center, Belgrade, Serbia and \\ ${ }^{2}$ Department of Medicine, Endocrinology Section, Complejo Hospitalario Universitario de Santiago, Santiago de \\ Compostela, Spain
}

\begin{abstract}
Recent data suggest that in addition to leptin's role in conveying signals of the amount of energy stores to the central nervous system, this adipocyte secreted hormone interacts with the endocrine system to provide critical information about the size of fat stores, acting as a permissive factor that allows the triggering of energy demanding situations as the onset of puberty and reproduction. Animal and human data are concordant with the concept that leptin plays an important permissive role in the initiation of puberty and in maintenance of reproductive function thereafter. Leptin regulates the gonadotropin-gonadal axis at a central level. The hypothalamus is an important site of leptin's action where a complex network of neuropeptides is involved in leptin's effect on GnRH. In addition, leptin plays a role during pregnancy and lactation as it is produced by the placenta and is present in milk. Plasma leptin levels are elevated during pregnancy and this hyperleptinemia is not accompanied by a reduction in food intake, suggesting a state of leptin resistance. Leptin is also detected in the amniotic fluid and its levels are high in venous cord blood at delivery correlating positively with weight at birth which suggests a potential role in intrauterine growth. The fact that in females leptin levels are higher than in males, even when corrected for body fat, suggests that the reproductive system is modulated by leptin in a different way in males and females estrogens. In hypoleptinemia resulting from specific genetic causes, leptin levels may still be adequate for the function of the reproductive system in humans, a phenomenon which differs from the findings in leptin-deficient animals which are infertile. Due to species differences in the role of leptin, it is difficult to extrapolate data from rodents to human physiology. However hypoleptinemia due to non-genetic causes such as anorexia nervosa and exercise leads to loss of reproductive function. Genetic/developmental factors influence the threshold required to turn off the behavioral, metabolic and endocrine responses to perceived caloric deprivation.
\end{abstract}

Key words: leptin, nutrition, energy balance, puberty, pregnancy

Address correspondence and requests for reprints to: Prof. Popovic Vera MD PhD, Institute of Endocrinology, 11000 Belgrade, Serbia, Fax: +381 11685 357, e-mail:popver@Eunet.YU

Received 29-03-02, Revised 10-06-02, Accepted 10-07-02

\section{LEPTIN AND NUTRITION}

It is well established that reproduction is very sensitive to nutritional status. Undernutrition delays the onset of sexual maturation and negatively affects sexual behaviour. It has been suggested that food availability is the most important factor that influences 
mammalian reproduction.

Our understanding of the links between nutrition and the reproductive axis is still incomplete despite important observations that timing of puberty is predicted more by body weight than by chronological age and that the level of body fat could in some way trigger initiation of reproductive function ${ }^{1,2}$. A major advance in the field was the discovery of the adipose tissue-derived hormone leptin, which strongly supported the concept that adipose tissue is an endocrine organ. Leptin is the $\mathrm{Ob}$ gene product secreted almost exclusively by fat cells and the serum leptin levels are proportional to adipocyte mass ${ }^{3}$.

Leptin is a potential signal to the brain reflecting both energy stores and energy balance (Figure 1). By signalling energy balance, leptin plays a role in regulating hunger and satiety, enabling the maintenance of normal weight $t^{4}$. The neuronal target for leptin is the hypothalamus where neurons in the arcuate nucleus, ventromedial and lateral hypothalamus express high levels of leptin receptor. Moreover, neuropeptides involved in feeding behaviour have been co-localized with leptin receptor ${ }^{5}$. As yet, it is not fully understood how human leptin levels are regulated and which metabolic functions are modulated by leptin. It does not seem that leptin modulates energy expenditure in humans because leptin levels correlate neither with resting metabolic rate nor with total energy expenditure $^{6}$. However, leptin is modulated by energy

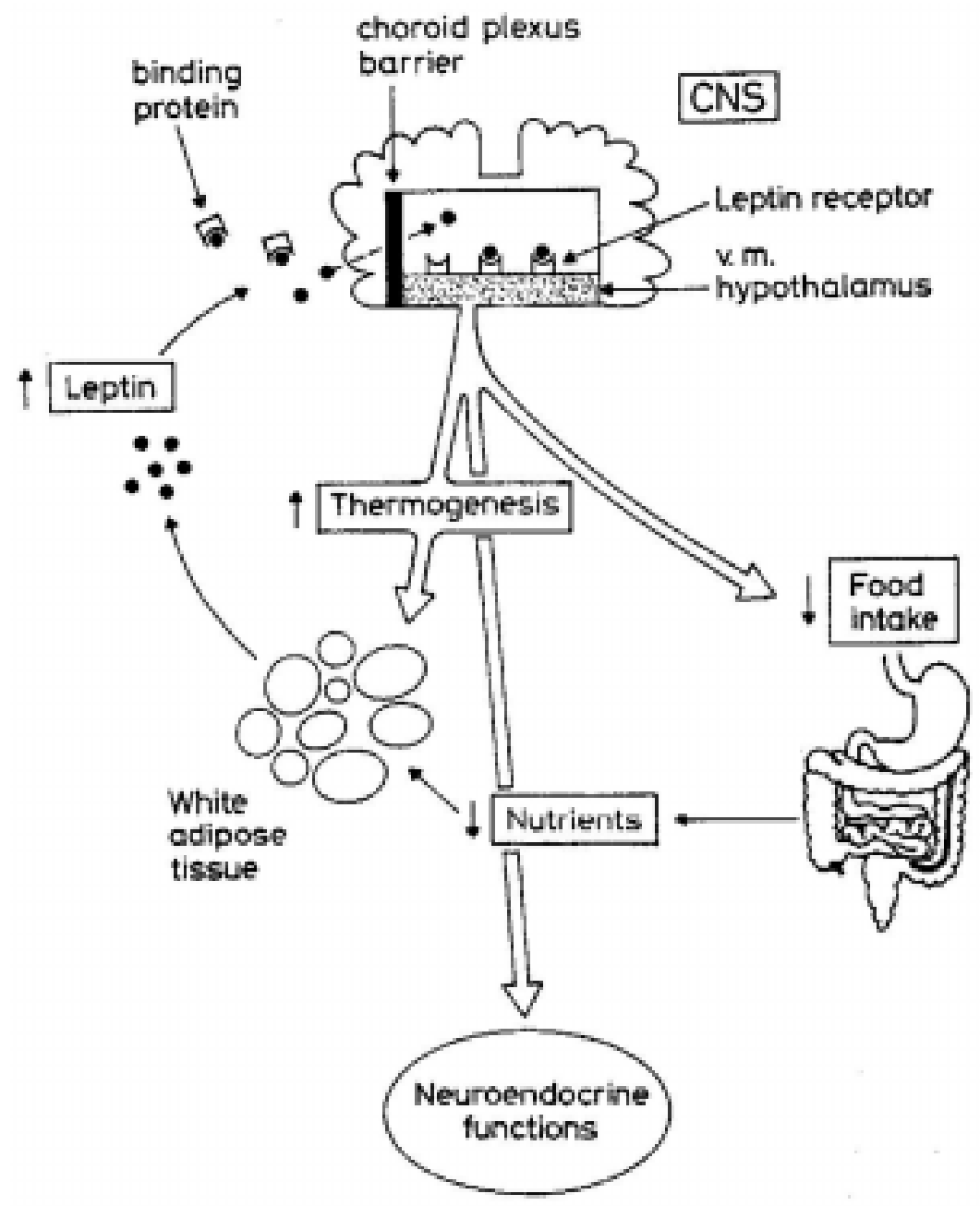

Figure 1. General scheme of leptin physiology. Leptin is secreted from the adipocytes and circulates as free and bound forms. At both the choroid plexous and the blood brain barrier, leptin is transported by a saturable system into the central nervous system (CNS) where it binds to specific receptors in ventromedial hypothalamus ${ }^{96}$. Reprinted with the permission of the publisher. 
balance. Leptin mediates the adaptation to fasting. Thus, with caloric restriction, leptin levels fall rapidly. Normally, a low leptin level signals starvation and directs the body to adapt to this condition. Furthermore, these changes in leptin precede changes in body weight. In the fed state, circulating levels of leptin and leptin messenger RNA levels are closely correlated with degree of adiposity. The leptin gene is over-expressed in adipose tissue in obese subjects. Obese subjects have been found to be resistant to the regulatory function of circulating leptin ${ }^{7,8}$.

A nocturnal rise in serum leptin was previously documented by 24-h sampling. This nocturnal rise in serum leptin level, regardless of the amount of fat mass in the body, therefore suggests an increase in the production rate of leptin and/or secretion rate. The nocturnal rise in leptin observed in both adults and adolescents ${ }^{9}$ resembles circadian rhythmicity of some hormones (PRL and TSH). As leptin levels increase at night, leptin pulsatile secretion becomes more organized and fluctuations of plasma leptin concentrations are synchronous with those of $\mathrm{LH}$ and estradiol ${ }^{10}$. Moreover, the patterns of synchrony of leptin/LH and leptin/estradiol are more orderly at night. Leptin stimulates biosynthesis of TRH in vitro and influences the activity of the hypothalamic-pituitary-thyroid axis in vivo in rodents. Leptin can increase the expression of the proTRH gene in hypothalamic TRH neurons ${ }^{11}$. TRH neurons are also subjected to negative regulation by serum thyroid hormone levels.In fasting, decreased serum thyroid levels are associated with a reduction in both TRH and TSH secretion ${ }^{12,13}$. Leptin administration to fasted mice decreased the fall in T4/ TSH induced by fasting ${ }^{14}$. It has been shown that leptin and TSH have almost identical circadian rhythms ${ }^{15}$. To further explore whether these associations could reflect an underlying regulation of TSH secretion by leptin, four brothers, members of a family with leptin deficiency were studied. Leptin levels of the homozygous leptin-deficient subject were detectable but bioinactive and the rhythm of his TSH was disorganized. In other heterozygous subjects, the $24 \mathrm{~h}$ pattern of leptin and TSH variability showed a weaker correlation compared with the strong correlation in the normal subjects ${ }^{15}$. These data may indicate that TSH secretion could be influenced by leptin's circulating levels. The mechanism by which leptin influences TSH rhythmicity remains largely unknown. The fact that caloric restriction results in a decrease in basal or
TRH-stimulated TSH levels, TSH pulse amplitude and nocturnal increase of TSH suggests that a factor that reflects nutritional status and energy stores could be responsible for these effects of caloric restriction. Thus, leptin and thyroid hormones have similar effects on thermogenesis and energy metabolism ${ }^{16}$.

More importantly, it has previously been shown that leptin's pulsatility is synchronous to that of gonadotropins. Since the pulsatilities of TSH and gonadotropins are concordant, a common hypothalamic pulse generator may regulate circulating concentrations of both hormones. Nutritional signals strongly regulate neuroendocrine axes such as those subserving release of $\mathrm{LH}, \mathrm{GH}$ and TSH presumably in part via the adipocyte derived neuroactive peptide, leptin. It has been suggested that the nocturnal increase in serum leptin in humans could be related to appetite suppression during sleep ${ }^{17}$ and to the meal pattern during the day ${ }^{18}$.

Twenty-four-hour leptin levels were shown to respond to cumulative short-term energy imbalance and to predict subsequent intake meaning that leptin maintains cumulative energy balance by modulating energy intake ${ }^{19}$. Thus three day overfeeding and three days underfeeding (short-term) in non-obese unrestrained eaters causes a $17 \%$ increase and $24 \%$ decrease in serum leptin levels and these changes are much larger than would be predicted by increases and decreases in body fat. Thus leptin release is controlled both by acute (fasting) and long term (adipose store) nutrient status ${ }^{19}$.

Furthermore inadequate nutritional intake profoundly alters neuroendocrine-metabolic functions in humans and experimental animals by activating the hypothalamic-pituitary-adrenal and/or somatotropic axes and by suppressing the reproductive axis ${ }^{20}$. Thus, the link between feeding behaviour and the long-term regulation of body weight and adiposity is mediated by hormones, for example, leptin, insulin, glucocorticoids and $\mathrm{GH}$, whose levels are related to energy stores ${ }^{5}$.

Limited information exists regarding the role of nutritional intake and substrate availability in the disruption of reproductive function in the absence of weight loss and exercise. Enhanced nocturnal GH secretion and reduced T3 and T4 together with hypercortisolemia support the view that compensatory metabolic adaptations to nutritional deficit may play a role in disrupting reproductive function ${ }^{21}$. The most important findings are those that link functional amen- 
orrhoea in weight stable, non-athletic women with severe restriction of dietary fat intake. Thus, subclinical eating disorders (50\% less fat consumption) may represent a common contributing factor in the development of multiple neuroendocrine-metabolic aberrations ${ }^{21}$.

Recently, it has been shown that leptin-GH (but not leptin-LH) showed nutrient dependent positive (fed) and negative (fasting) cross-correlations in a study of short-term fasting in the steroid-replete midlutheal phase of the normal menstrual cycle in healthy young women ${ }^{22}$. Short-term fasting selectively suppresses leptin pulse mass and $24 \mathrm{~h}$ rhythmic leptin release without disturbing leptin pulse frequency or its pattern of regularity. No correlation could be found between leptin-LH in healthy normal cycling women ${ }^{23}$. Thus, leptin is a sensitive integrated marker of nutritional status, i.e. hypoleptinemia, independent of fat mass, may reflect inadequate calorie intake, fat intake and/or other subclinical nutritional disturbances in women with functional amenorrhoea ${ }^{22}$. Not unexpectedly then, normal GnRH neuronal activity is dependent on sufficient energy availability. Since there are only a few papers that have attempted to examine the relationship between leptin and metabolic fuel availability, it is difficult to evaluate the degree to which these pathways interact.

\section{LEPTIN DEFICIENCY INDEPENDENT OF STARVATION}

Conditions associated with leptin absence or deficiency not associated with starvation are rare. They are the result of mutations in the leptin gene, are associated with morbid obesity from infancy and have a number of hormonal abnormalities, including insulin resistance and hypogonadotropic hypogonadism ${ }^{24-26}$. While multiple lines of evidence suggest that leptin plays a key role in reproduction (Figure 2), the identification of patients with severe lipodystrophy caused by a deficiency or destruction of adipose cells characterized by low leptin levels and who have normal reproductive function demonstrates all the complexity in understanding the system ${ }^{27}$. Abnormalities in this condition (hypertriglyceridemia and insulin resistance) can be corrected by leptin replacement therapy. Leptin replacement led to clear and dramatic metabolic benefits in patients with lipodystrophy and leptin deficiency ${ }^{28}$.

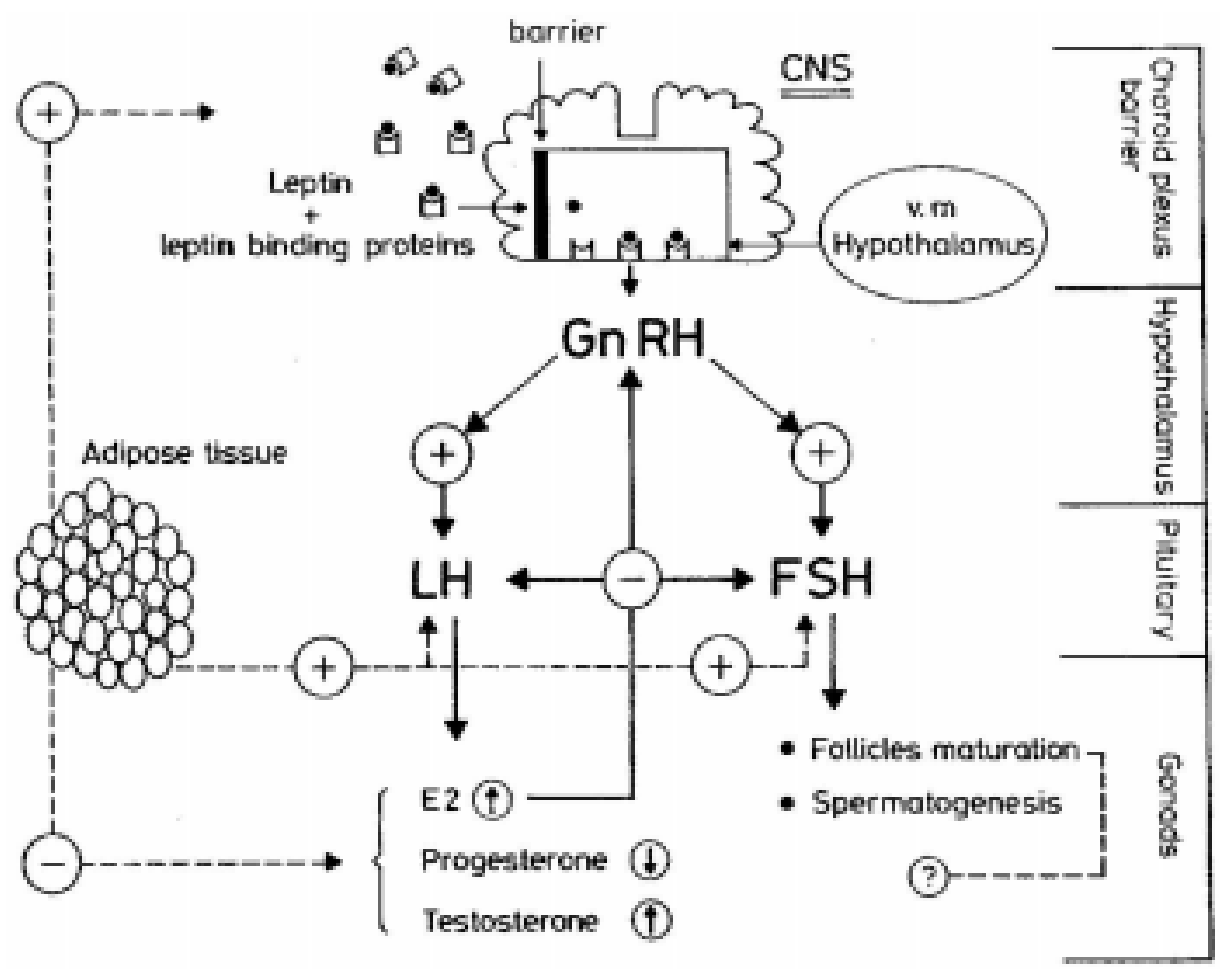

Figure 2. Leptin action on hypothalamic-pituitary-gonadal axis in both sexes. 


\section{LEPTIN, GENDER, SEX HORMONES}

From the initial reports of leptin measurements in humans, it was evident that a clear gender difference in leptin levels existed (Figure 3), i.e. leptin levels were found to be two to threefold higher in women than in men for the same BMI values. The gender difference in circulating leptin levels, even after correcting serum leptin levels for percent or total body fat, indicated that an endocrine involvement may be at the basis of gender difference. Sex differences in serum leptin levels have been identified across a broad spectrum of age, body mass index and body fat. Several mechanisms have been postulated to explain the physiological basis for this sexual dimorphism in plasma leptin concentration $^{29}$. Accumulating evidence suggests that a) leptin production per unit fat mass is $75 \%$ higher in women ${ }^{30}$ and accelerated secretion rates of leptin from adipose tissue are due to increased leptin gene expression $^{31}, b$ ) pre-menopausal females have higher leptin levels than post-menopausal after correction for differences in body composition ${ }^{32}$ and post-menopausal women still have leptin levels significanlty greater than males; c) female adipose tissue may be more sensitive to hormones (insulin, glucocorticoids) $)^{33}$; d) estrogens alter the balance between long and short leptin receptor isoforms leading to increased tissue sensitivity to leptin ${ }^{34}$; and e) sex hormones may regulate leptin binding proteins. Furthermore, in a study con-

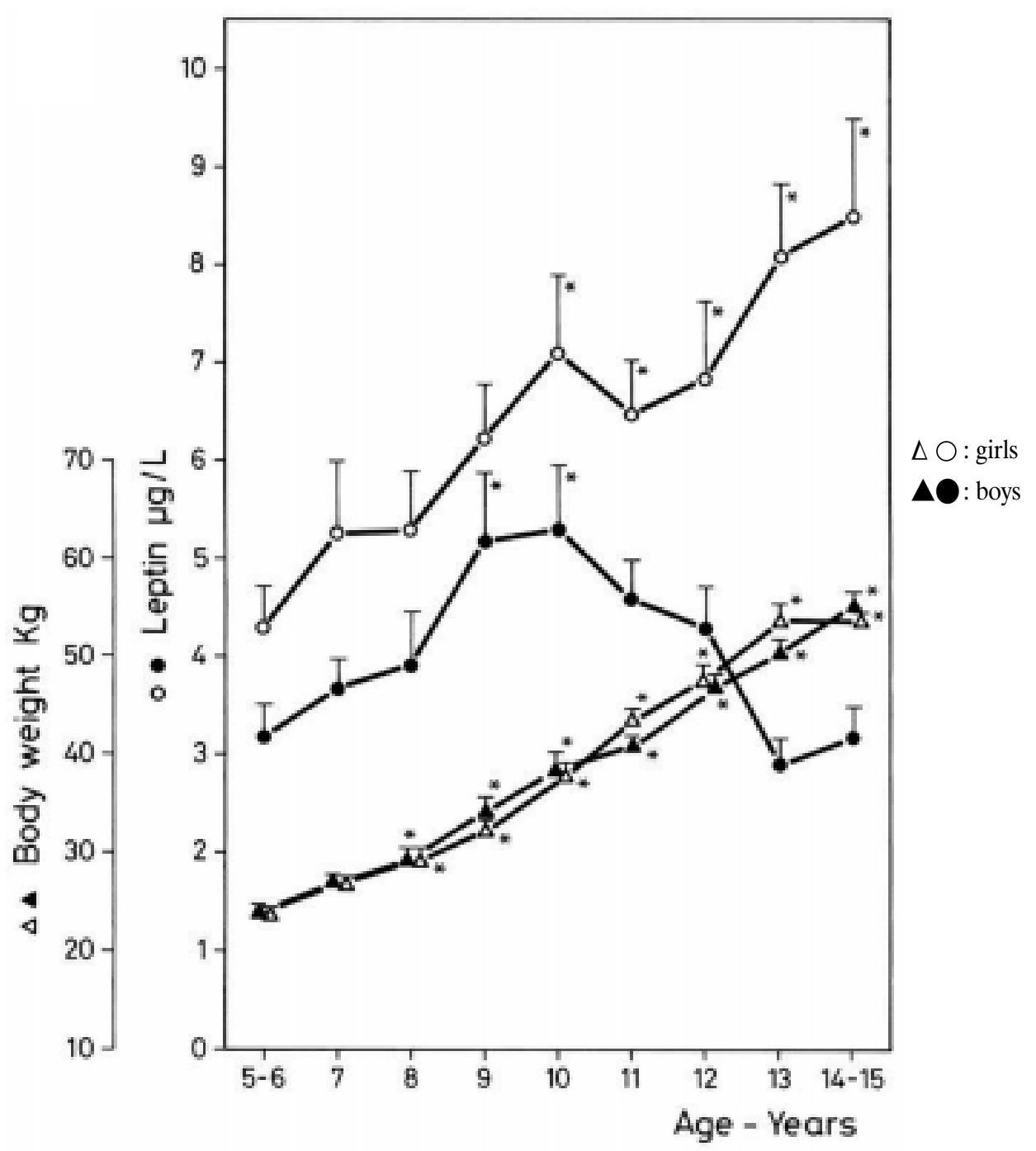

Figure 3. Mean+SEM of serum leptin concentrations in normal children of both sexes ordered by age groups and plotted against their respective body weight ${ }^{61}$. Reprinted with the permission of the publisher. 
ducted in transsexuals undergoing sex reassignment following a standard protocol of cross sex-hormone administration, it has been shown that sex steroid hormones, in particular testosterone, play an important role in the regulation of serum leptin levels ${ }^{35}$.

Higher leptin levels are found in normally cycling women when compared with postmenopausal women and in addition, leptin levels increase with spontaneous follicle development in the normal menstrual cycle. Higher leptin levels in the luteal compared with the follicular phase of normal cycles suggests that progesterone may also be involved in the hormonal regulation of leptin secretion. However, an approximately $20 \%$ increase in leptin levels with physiological estrogen replacement, which has been demonstrated in postmenopausal women, is considerably less than the $40 \%$ difference observed between men and women ${ }^{36,37}$. Nevertheless, an effect of estrogen alone is insufficient to explain the sexual dimporphism in leptin levels.

On the other hand, there is evidence suggesting that testosterone exerts a negative regulation on leptin secretion ${ }^{38}$. We found that chronically elevated basal testosterone levels, in two virilized females harbouring testosterone-secreting ovarian tumours, were associated with suppressed serum leptin levels to the extent that the gender difference in leptin levels was $\operatorname{lost}^{39}$. Prior to surgery, increased lean mass and decreased fat mass in one of our patients confirmed that testosterone modifies body composition parameters in favour of fat-free mass. We also found that acute changes in plasma testosterone levels per se did not affect circulating serum leptin levels two weeks after curative surgery. Furthermore, dihydrotestosterone, stanozolol, androstenedione and dehydroepiandrosterone sulphate induced a significant inhibition of leptin secretion in vitro for omental adipose tissue, derived from females but an analogous effect was not observed in male samples. Testosterone was devoid of activity in either gender ${ }^{40}$. Thus in adipose tissue samples derived from female donors, androgens act, in general, as suppressors of leptin secretion while estradiol stimulates leptin release as has been previously shown in animal studies ${ }^{41,42}$. Neither androgens nor estrogens are able to modulate in vitro leptin secretion by adipose tissue taken from male subjects ${ }^{28}$

The lack of a direct effect of testosterone on leptin secretion by adipocytes has been reported ${ }^{43}$ and a rise of testosterone up to two to three times above the baseline after hCG stimulation for 3-5 days did not modify plasma leptin concentrations in normal weight and obese men ${ }^{44}$. Because testosterone increases muscle size and modifies body composition parameters in favour of fat-free mass, it cannot be excluded that a relevant part of the claimed androgen effects on leptin are indirect and are exerted through changes in body composition, fat content and adipose tissue distribution.

Elevated androgen levels in women with polycystic ovarian disease do not modify plasma leptin levels $^{45,46}$. In a group of hyperandrogenic, nondiabetic women with insulin resistance, acantosis nigricans and irregular cycles, the administration of desogestrol-containing oral contraceptive decreased total and free testosterone without affecting leptin levels ${ }^{47}$. These women were extremely obese and did not change their BMI during the six-cycle follow-up period. However, body composition studies were not performed and these patients were taking high dose of estrogens (30mg of ethinyl estradiol). Estrogens contribute in part to the differences in serum leptin levels observed between men and women but do not constitute the only mechanism.

\section{LEPTIN - OTHER HORMONES}

Apart from fat mass, gender and sex hormones, there are a number of other postulated influences on the circulating leptin level. In humans, insulin ${ }^{48}$, glucocorticoids $^{49,50}$ and growth hormone ${ }^{51-53}$ have been claimed to stimulate or inhibit leptin secretion. Insulin can regulate leptin expression and stimulate leptin secretion, at least in part through the lipogenic effect of insulin on adipocytes. On the other hand, growth hormone is not only involved in growth and development but also has an important impact on body composition and fat distribution through its influence on energy metabolism and its lipolytic and nitrogen sparing effects. In rodents, leptin stimulates GH secretion, particularly when leptin is infused centrally. The administration of leptin antiserum to normally fed rats led to a decrease in spontaneous GH secretion while administration of leptin to fasted rats was followed by a reversal of the fasting-induced suppression of GH secretion ${ }^{51,54}$. Since regulation of GH secretion in humans is different from rodents, it is difficult to translate these results to humans and no pertinent human data are available. Some consider leptin as a possible 
metabolic signal inhibiting $\mathrm{GH}$ secretion, while $\mathrm{GH} /$ IGF-I could also be involved in the regulation of leptin secretion ${ }^{55}$. Recent data showed an effect of an acute bolus of GH on serum leptin in normal individuals. A single bolus of GH significantly increased serum leptin levels in the absence of a change in body composition. Fasting increases $\mathrm{GH}$ and decreases leptin in both sexes.GH and leptin secretions are higher in women than in men in the fed state but not in fasting, which abolishes the gender-related differences in humans ${ }^{57}$. At present, however, the respective roles of hormonal factors in the overall regulation of leptin production have not been fully ascertained. Leptin significantly correlates with other homones, but not independently of body composition ${ }^{58}$.

\section{LEPTIN- HYPOTHALAMUS AND TIMING OF PUBERTY}

Leptin clearly influences reproduction but where leptin acts to exert this effect is not yet fully resolved. Leptin most likely exerts its most important effects through CNS and specifically through the hypothalamus. Although several lines of evidence suggest that the hypothalamus is the primary brain site targeted by leptin ${ }^{59}$, the precise site within the hypothalamus cannot be ascertained at present. A number of hypothalamic neuropeptides important in the feeding behaviour have been examined as leptin effectors. Perhaps the subpopulation of NPY-producing cells in the hypothalamus may be one of the targets of leptin action. Nevertheless, it has not as yet been elucidated via which of the peptidergic neurons leptin infuences GnRH secreting cells. Leptin receptor (OB-R) has homology to members of the class I cytokine receptor family, which may imply similarities in molecular events in intracellular signal transduction engaged by cytokines and leptin ${ }^{61}$. The long form of leptin receptor responsible for signal transduction is expressed in the arcuate nucleus, an area important for controlling GnRH release and sexual behavior. Leptin at the lowest concentrations in vitro caused a significant increase in GnRH release form rodent arcuate nucleus explant $^{60}$. To further assess whether or not the effect of leptin on GnRH is direct, an immortalized GnRHsecreting neuronal line was treated with leptin ${ }^{61}$ and it was shown that leptin stimulated GnRH release. Leptin receptors, however, have not thus far been identified on GnRH neurons. The already mentioned cir- cadian and the pulsatile patterns of fluctuations in serum leptin levels imply that neural and neurohumoral components of the brain may regulate leptin secretion from adipocytes. The nocturnal increase in leptin, GH and IGF-1 secretion prior to puberty in the agonadal male monkey provide evidence for the role of leptin in regulating increases in pulsatile nocturnal gonadotropin-releasing hormone secretion during development ${ }^{62}$. In humans, leptin mutation delays pubertal onset but does prevent it. A number of studies in animals which examined whether leptin adimistration could accelerate pubertal onset were inconclusive, i.e. some did show acceleration while others failed to show an effect of leptin in accelerating pubertal onset ${ }^{63-66}$. Several studies in humans have reported a progressive increase in leptin levels during childhood and the prepubertal period in both sexes ${ }^{67-70}$. Furthermore, during reversible pituitary-gonadal suppression in children with central precocious puberty, suppression of testosterone increased leptin levels whereas resumption of puberty was associated with decreased leptin levels ${ }^{71}$.

In the oldest female from a Turkish consanguineous family with missense leptin gene mutation, there was a delay of over 20 years in the onset of regular menstruation. Since hypogonadism is a clinical feature of leptin gene mutation,one must conclude that leptin acts in a permissive way and is only one of several metabolic factors important for the onset of puberty.

The relatively stable circulating concentrations of leptin across the boundary between prepubertal life and sexual maturation would suggest that although a certain plasma threshold of leptin is a requisite for sexual development, achieving this threshold is insufficient to activate the reproductive axis before normal timing of the event. Clearly, other factors besides leptin are necessary for the initiation of sexual maturation in humans ${ }^{72}$.

\section{IMPORTANT SPECIES DIFFERENCES IN THE ROLE OF LEPTIN}

Rodents without leptin have reduced basal metabolic rate in contrast to humans. Leptin may be less central to the regulation of energy expenditure in humans than in mice ${ }^{73}$. Regulation of growth hormone in starvation in rodents is different from humans; $\mathrm{GH}$ 
response to starvation is blunted in rodent while in humans it is stimulated. Decreased GH secretion in rodents is reversed by administration of leptin. A further difference between rodents and humans relates to the consistently normal glucocorticoid concentrations in humans with leptin deficiency in contrast to the marked excess in ob/ob mice. Thus, due to the existence of these important interspecies differences the extrapolation of data from rodent to human physiology is not feasible.

\section{LEPTIN IN CHRONIC UNDERNUTRTION AND LOW BODY FAT}

The importance of energy stores in maintaining fertility is best demonstrated by the menstrual cycle dysfunction commonly found in women who lose weight below a certain threshold level ${ }^{74,75}$. Such women have low plasma levels of estrogen, $\mathrm{LH}$ and FSH, with a circadian pattern of LH secretion similar to that of pre-pubertal girls.In patients with anorexia nervosa a pre-pubertal pattern of gonadotropin secretion is found. Animal studies have shown marked delay in the onset of puberty in food deprived animals and a rapid recovery of reproductive function when food is available ad libitum ${ }^{76}$. Similarly, females undertaking chronic strenuous exercise develop the so-called exercise-induced amenorrhea ascribed to loss of weight, low percentage of fat, increase expenditure of energy or decreased energy intake, with the consequent loss of pulsatile LH secretion, which is rapidly resolved when exercise ceases ${ }^{77}$. These findings suggest that "metabolic stress", with or without weight loss, may affect the reproductive axis more severely in women and that leptin may well be the mediator of this metabolic stress to the GnRH generator. Leptin is able to prevent the reduced pulsatile $\mathrm{LH}$ secretion that occurs during fasting in monkeys and rats ${ }^{78}$.

Women in a state of self-induced starvation (anorexia nervosa) show extremely low levels of serum leptin without nocturnal rise ${ }^{79}$. The low leptin levels correlate with the reduction in adipose stores but are unrelated to the type of nutritional disease involved ${ }^{80}$. Although dynamic changes in serum and CSF leptin have been shown with changes in nutrition or body weight ${ }^{81}$, leptin values show a delay in recovery in comparison with fat mass restoration. Leptin levels in cerebrospinal fluid (CSF) correlate with the nutritional status, but the CSF to plasma leptin ratio is higher for patients than for controls and normalizes before body weight is normalized ${ }^{81}$. It may be hypothesized that differences in the recovery of leptin levels may be the basis for persistent absence of menses in some patients after body weight normalization, a fairly common clinical finding. The relationship between leptin, percent body fat and nutritional variables including insulin-like growth factor I (IGF-I) was compared in patients with anorexia nervosa and normal controls. These data suggest that nutritional factors other than percent body fat may control leptin secretion, for example, disordered eating behaviour, low fat consumption and low insulin-like growth factor I (IGF-I). Low serum leptin levels are found in young amenorrheic athletes ${ }^{82}$ without nocturnal rise in serum leptin levels while athletes with similar BMI who had regular cycles consumed more fat in their diets and had nocturnal rise in serum leptin level ${ }^{82}$.

\section{LEPTIN AND PREGNANCY}

Pregnancy is a hypermetabolic state in which a great increase in maternal body fat and weight occurs, mostly in the final trimester, associated with relevant neuroendocrine changes. In order to verify to what degree leptin influences the changes in appetite, thermogenesis, lipid metabolism and neuroendocrine adaptations during pregnancy, this hormone has been measured in several animal models and in humans. A clear association of prolactin and leptin is found in pregnancy and lactation. Leptin and prolactin rise in pregnancy in a parallel manner and regression analysis suggests that body mass index and prolactin can be used as predictors of leptin values. It is thought that prolactin and leptin mediate partitioning of nutrients for energy utilization in a state of increased energy demands such as pregnancy and lactation $^{83}$. Leptin levels are high in the mother throughout gestation and especially around term and in the fetus at term ${ }^{84}$. In the first trimester of pregnancy, plasma leptin increases before any major changes in body fat and resting metabolic rate ${ }^{85,86}$ and these changes are unrelated to the fetal growth ${ }^{87}$. Immediately before delivery, leptin levels undergo a dramatic reduction returning to the levels of non-pregnant women $24 \mathrm{~h}$ pre-partum with further decrease after delivery . At least in rodents, high leptin levels are, in part due to a complex of leptin-leptin binding protein ${ }^{88}$. There is no clear explanation for the role of increased leptin in human pregnancy and the mechanisms by which 
maternal and fetal weight are regulated. Leptin increase may be due to pregnancy-derived increase in leptin resistance and a probable explanation is the need to maintain increased food intake in the mother, despite already increased adiposity, in order to further build up energy stores for lactation ${ }^{89}$. Elevated levels of leptin in pregnancy may also come from human placent $\mathrm{a}^{90,91}$. The continuous increase in leptin levels during pregnancy may raise the set point of the hypothalamic leptin receptor and this may explain the postpartum weight retention or weight increase reported by some women. Leptin is detectable in fetal blood as early as 18 weeks of gestation, with a dramatic increase at 34 weeks $^{92,93}$. This rise parallels adipose tissue development during the second trimester of gestation and its exponential increase in the last weeks of gestation. It is important to underline that fetal leptin levels correlate with the amount of fetal fat but not with maternal leptin levels. Whether leptin merely reflects changes in adipose stores or whether it has a more complex role in embryonic development is unknown at present. The latter possibility is supported by the detection of leptin gene expression in a variety of murine fetal tissues, such as cartilage, bone, brain, hair follicles, etc. At birth, neonatal leptin levels are lower in comparison with the antenatal values. Cord leptin levels in female babies are $40 \%$ higher than in male, indicating that the gender differences are present even in intra uterine life ${ }^{94,95}$. Leptin levels at birth are disproportionately high in neonates and reach adult values two weeks post partum, both in rodents and humans. These data strongly reinforce the notion that circulating leptin levels may provide a growth-promoting signal for fetal development during late pregnancy ${ }^{96}$.

\section{LEPTIN DURING ASSISTED REPRODUCTIVE THERAPY}

A role for leptin in ovarian physiology is well accepted and important changes in serum leptin levels are found during ovarian suppression-stimulation programmes for assisted reproductive cycles. Moreover, women with successful pregnancy outcomes have higher leptin levels after embryo transfer and in early pregnancy than those failing to achieve pregnancy or those with later fetal loss. Ovarian stimulation by hMG/FSH is accompanied by significant rise in leptin. Since the peak of leptin appears after the rise of estrogens, it is possible that estrogens rather than FSH itself are the main mechanism of the leptin rise ${ }^{97}$. A significant increase in serum leptin levels of about $60 \%$ is observed from suppression to ovarian hyperstimulation during in vitro fertilization techniques ${ }^{98}$. Moreover, the follicular fluid leptin concentrations at the time of oocyte retrieval are similar to the serum concentrations. Leptin synthesis has also been demonstrated in ovarian granulosa $^{99}$. The increase in leptin level is negatively correlated with the ovarian response as measured by the number of follicles and oocytes. A positive correlation between the percentage of change in leptin concentrations with the percentage of FSH increase is observed. Follicular fluid leptin concentrations were measured in women who underwent several In Vitro Fertilizations (IVF) or Gamete Intra-Fallopian Transfers (GIFT) and it was found that women who succeeded in becoming pregnant within three cycles of IVF or GIFT had significantly lower leptin concentrations in follicular fluid in comparison with women who failed to become pregnant within three cycles, after adjusting for age and $\mathrm{BMI}^{100}$. In summary, low follicular fluid leptin concentration may be a marker of success after IVF.

To add further to the complexity of leptin-mediated regulation of gonadal function, direct actions of leptin on gonads have recently been reported ${ }^{101}$. Leptin has been shown to inhibit the synergistic action of insulin-like growth factor I and FSH on granulosa cell estradiol production ${ }^{102}$. It is possible that leptin in high concentrations can act as an inhibitory co-gonadotropin in the ovary ${ }^{103}$. The increased leptin production during ovarian hyperstimulation may be related to adiposity and reduced ovarian responsiveness to FSH administration.

\section{SUMMARY AND CONCLUSIONS}

Although leptin was originally viewed as an antiobesity hormone, it is now evident that it may have more pleiotropic actions. Experiments in rodents have shown that leptin activates the sympathetic nervous system, and is involved in regulation of blood pressure, hematopoiesis, immune function, angiogenesis and brain and bone development. The hypothalamus is the primary brain site targeted by circulating leptin secreted by fat cells. Leptin acts through its receptor which has homology to members of the class I cytokine receptor family and that may imply similarities in 
molecular events engaged by cytokines and leptin. Leptin is a potential signal to the brain reflecting both energy stores and energy balance. By signalling energy balance, leptin plays a role in regulating hunger and satiety and the maintenance of normal boby weight. The diverse actions of leptin on feeding, metabolism and neuroendocrine responses probably involve differential regulation of neuronal circuits in the hypothalamus and brain stem. While in experiments with hypothalamic explants and a GnRH -secreting neuronal cell line leptin directly stimulates GnRH secretion, the lack of leptin receptor on GnRH neurons suggests that leptin may act indirectly through other neuropeptides to stimulate $\mathrm{CnRH}$ secretion. In view of cytokine-like properties of the leptin receptor, it is likely that leptin produced and secreted outside of fat tissue, (CNS, pituitary, ovary, placenta, etc) acts as a paracrine regulator. Infertility is an inherent part of the leptin-deficient mouse $(\mathrm{Ob})$ which is corrected by the administration of leptin. Administration of leptin to starved mice reverses the starvation-induced diminution in circulating gonadotropins and gonadal steroids and restores ovulatory function. Although pubescence and fertility are not synonymous, leptin administration has been shown to hasten the onset of puberty in rodents. Some biological effects observed in rodents have so far not been seen in humans. Thus, due to species differences in the role of leptin it is difficult to extrapolate data from rodents to human physiology. Leptin seems to have a permissive but not a primary role in the timing of puberty in humans. It has been proposed that low leptin levels resulting from genetic causes may still be adequate for a functioning reproductive system but the exact underlying mechanism for this effect is still not known. On the other hand, low leptin levels with amenorrhoea and infertility are frequently observed in individuals with a reduced body weight secondary to vigorous exercise and/ or caloric restriction. Leptin mediated signals appear to provide a critical link between somatic energy stores, energy homeostasis and fertility. Genetic/developmental factors influence the threshold required to turn off the behavioural, metabolic and endocrine responses to perceived caloric deprivation. Prospects for therapeutic strategies might be that exogenous leptin could have some clinical utility in facilitating compliance with hypocaloric diet and in maintenance of a reduced body weight as well as in restoring menstrual function, ovulation and fertility in individuals with low fat mass.

\section{REFERENCES}

1. Frisch R, Revelle R, 1970 Height and weight at menarche and a hypothesis of critical body weights and adolescent events. Science 169: 397-399.

2. Frisch R, McArthur J, 1974 Menstrual cycles: fatness as determinant of minimum weight for hheight necessary for their maintenance or onset. Science 185: 949-951.

3. Zhang Y, Proenca R, Maffei M, Barone M, Leopold L, Friedman J, 1994 Positional cloning of the mouse obese gene and its human homologue. Nature 372: 425-432.

4. Flier J, 1998 What's in a name? In search of Leptin's Physiologic Role. J Clin Endocrinol Metab 83:1407-1413.

5. Ahima R, Osei S, 2001 Molecular regulation of eating behavior: new insights and prospects for therapeutic Strategies. Trends in Molecular Medicine 7: 205-213.

6. Martin L, Jones P, Considine R, Su W, Boyd N, Caro J, 1998 Serum leptin levels and energy expenditure in normal weight women Can. J Physiol Pharmacol 76: 237-241.

7. Considine RV, Sinha MK, Heiman ML, Kriauciunas A, Stephens TW, Nyce MR, Ohannesian JP, Marco CC, McKee LJ, Bauer TL, Caro JF, 1996 Serum immunoreactive-leptin concentrations in normal-weight and obese humans. N Engl J Med 334: 292-295.

8. Bray G, York D, 1997 Leptin and clinical medicine: a new piece in the puzzle of obesity $\mathrm{J}$ Clin Endocrinol Metab 82: 2771-2776.

9. Matkovic V, Ilich J, Badenhop N, Skugor M, Clairmont A, Klisovic D, Landoll J, 1997 Gain in body fat is inversely related to the nocturnal rise in serum leptin level in young female J Clin Endocrinol Metab 82: 1368-1372.

10. Licinio J, Negrado A, Mantzoros C, et al, 1998 Synchronicity of frequently sampled $24 \mathrm{~h}$ concentrations of circulating leptin, luteinizing hormone and estradiol in healthy women. Proc Natl Acad Sci 95: 2541-2546.

11. Legradi G, Emerson C, Ahima R, Flier J, Lechan R, 1997 Leptin prevents fasting-induced suppression of prothyrotropin-releasing hormone messenger ribonucleic acid in neurons of the hypothalamic paraventricular nucleus. Endocrinology 138: 2569-2576.

12. Blake N, Eckland D, Foster O, Lightman S, 1991 Inhibition of hypothalamic thyrotropin-releasing hormone messenger ribonucleic acid during food deprivation. Endocrinology 129: 2714-2718.

13. Rondeel J, Heide R, Greef W, et al, 1992 Effect of starvation and subsequent refeeding on thyroid function and release of hypothalamic thyrotropin-releasing hormone. Neuroendocrinology 56: 348-353.

14. Ahima R, Prabarkan D, Mantzoros C, et al, 1996 Role of leptin in the neuroendocrine response to fasting. Nature 382: 250-252.

15. Mantzoros C, Ozata M, Negrao A, Suchard M, Ziotopoulu M, Caglayan S, Elashoff R, Cogswell R, Negor P, Liberty V, Wong M, Veldhuis J, Ozdemir C, Gold P, Flier J, Licinio J, 2001 Synchronicity of frequently sampled thyro- 
tropin (TSH) and leptin concentrations in healthy adults and leptin-deficient subjects: evidence for possible partial TSH regulation by leptin in humans. J Clin Endocrinol Metab 86: 3284-3291.

16. Wauters M, Considine R, Gaal L, 200 Human leptin: from an adipocyte hormone to an endocrine mediator. Eur $\mathbf{J}$ Endocrinol 43: 293-311.

17. Sinha M, Ohannesian J, Heiman M, et al, 1996 Nocturnal rise in leptin in lean, obese, and non-insulin-dependent diabetes mellitus. J Clin Invest 97: 1344-1347.

18. Schoeller D, 1997 Entrainment of the diurnal rhythm of plasma leptin to meal timing. J Clin Invest 100: 1882-1887.

19. Chin-Chance C, Polonsky K, Schoeller D, 2000 Twentyfour-hour leptin levels respond to cumulative short-term energy imbalance and predict subsequent intake. J Clin Endocrinol Metab 85: 2685-2691.

20. Natagani S, Zeng Y, Keisler D, Foster D, Jaffe C, 2000 Leptin regulates pulsatile luteinizing hormone and growth hormone secretion in the sheep. Endocrinology 141: 39653975.

21. Laughlin GA, Dominguez C, Yen S, 1998 Nutritional and endocrine-metabolic aberrations in women with functional hypothalamic amenorrhea. J Clin Endocrinol Metab 83: 25-32.

22. Miller K, Parulekar M, Schoenfeld E, Anderson E, Hubbaed J, Klibanski A, Grinspoon S, 1998 Decreased leptin levels in normal weight women with hypothalamic amenorrhoea: the effects of body composition and nutritional intake. J Clin Endocrinol Metab 83: 2309-2312.

23. Bergendahl M, Iranmanesh A, Evans W, Veldhuis J, 2000 Short-term fasting selectively suppresses leptin pulse mass and 24-hour rhythmic leptin release in healthy midlutheal phase women without disturbing leptin pulse frequency or its entropy control pattern orderliness. J Clin Endocrinol Metab 85: 207-213.

24. Clement K, Vaisse C, Lahlou N, et al, 1998 A mutation in the human leptin receptor gene causes obesity and pituitary dysfunction. Nature 392:398-401.

25. Ozata M, Ozdemir C, Licinio J, 1999 Human leptin deficiency caused by a missense mutation: multiple endocrine defects, decreased sympathetic tone and immune system dysfunction indicate new targets for leptin action, greater central than peripheral resistance to the effects of leptin and spontaneous correction of leptin mediated defects. J Clin Endocrinol Metab 84: 3686-3696.

26. O'Rahilly S, 1998 Life without leptin. Nature 392: 330331.

27. Andrelli F, Hanaire-Broutin H, Laville M, Tauber J, Riou J, Thivolet C, 2000 Normal reproductive function in leptin-deficient patients with lipoatropic diabetes. J Clin Endocrinol Metab 85: 715-719.

28. Oral E, Simha V, Ruiz E, et al, 2002 Leptin-replacement therapy for lipodystrophy. N Engl J Med 346: 570-578.

29. Casabiell X, Pineiro V, Vega F, de la Cruz L, Dieguez C, Casanueva FF, 2001 Leptin, reproduction and sex steroids. Pituitary 4: 93-99.

30. Lonqvist F, Armer P, Nordfors L, Schalling M, 1995 Overexpression of the obese $(\mathrm{Ob})$ gene in adipose tissue of human obese subjects. Nat Med 1: 950-953.

31. Licinio J, Negrado A, Mantzoros C, Kaklamani V, Wong M, Bongiorn P, Negro P, Mulla A, Veldhuis J, Cearnal L, Flier J, Gold P, 1998 Sex differences in circulating human leptin pulse amplitude: clinical implications. J Clin Endocrinol Metab 83: 4140-4147.

32. Rosenbaum M, Nicolson M, Hirsch J, Heymsfield S, Gallagher D, Chu F, Liebl R, 1996 Effects of gender, body composition and menopause on plasma concentrations of leptin. J Clinl Endocrinol Metab 18: 3424-3428.

33. Tritos \& Mantzoros, 1997 Leptin: its role in obesity and beyond. Diabetologia 40: 1371-1379.

34. Benett P, Lindell K, Karlsson C, Robinson I, Carlsson L, Carlsson B, 1998 Differential expression and regulation of leptin receptor isoforms in the rat brain: effects of fasting and estrogen. Neuroendocrinology 67: 29-36.

35. Elbers J, Asscheman H, Seidell J, Frolich M, Meinders E, Gooren L, 1997 Reversal of the sex difference in serum leptin levels upon cross-sex hormone administration in transsexuals. J Clin Endocrinol Metab 82: 3267-3270.

36. Lavoie H, Taylor A, Sharpless J, Anderson E, Strauss C, Hall J, 1999 Effects of short-term hormone replacement on serum leptin levels in postmenopausal women. Clinl Endocrinol 51: 415-422.

37. Elbers J, de Valk - de Roo G, Popp-Snijders C, NicolaasMerkus A, Westerveen E, Joenje B, Netelenbos J, 1999 Effects of administration of 17 beta-oestradiol on serum leptin levels in healthy postmenopausal women. Clin Endocrinol 51: 449-454.

38. Jockenhovel F, Blum W, Vogel E, et al, 1997 Testosterone substitution normalizes elevated serum leptin levels in hypogonadal men J Clin Endocrinol Metab 82: 25102513.

39. Pekic S, Vujovic S, Spremovic-Radjenovic S, Petakov M, Djurovic M, Damjanovic S, Micic D, Dieguez C, Casanueva FF, Popovic V, 2001 Loss of gender difference in serum leptin levels and its slow recovery after successful surgery for Leydig cell tumours in two virilized females. Clin Endocrinol (Oxf) 54: 693-697.

40. Piceiro V, Casabiell X, Peiny R, Lage M, Camica J, Menedez C, Baltar J, Dieguez C,. Casanueva FF, 1999 Dihydrotestosterone, stanozolol, androstenedione and dehydroepiandrosterone sulphate inhibit leptin secretion in female but not in male samples of omental adipose tissue in vitro: lack of effect of testosterone. J Endocrinol 160: 425-432.

41. Sivan E, Whittaker P, Sinha D, et al, 1998 Leptin in human pregnancy: relationship with gestational hormones. Am J Obstet Gynecol 179: 1128-1132.

42. Shimizu H, Shimomura Y, Nakanishi Y, et al, 1997 Estrogen increases in vivo leptin production in rats and human subjects. J Endocrinol 154: 285-292.

43. Popovic V, Micic D, Petakov M, 1998 Testosterone does not affect leptin secretion by adipocyte in vivo and in vitro evidence. Proc 80th Meeting of the Endocrine Society, New Orleans, LA; pp, 2-536.

44. Isidori A, Caprio M, Strollo F, Moretti C, Frajese G, Isidori A, Fabbri A, 1999 Leptin and androgens in male obes- 
ity: evidence for leptin contribution to reduced androgen levels. J Clin Endocrinol Metab 84: 3673-3680.

45. Laughlin GA, Morales AJ, Yen SS, 1997 Serum leptin levels in women with polycystic ovary syndrome: the role of insulin resistance/hyperinsulinemia. J Clin Endocrinol Metab 82: 1692-1696.

46. Micic D, Macut Dj, Popovic V, Sumarac M, Kendereski A, Colic M, Dieguez C, Casanueva FF, 1997 Leptin levels and insulin sensitivity in obese and non-obese patients with polycystic ovary syndrome. Gynecol Endocrinol 11: 315-320.

47. Nader S, Riad-Gabriel M, Saad M, 1997 The effect of a desogestrel-containing oral contraceptive on glucose tolerance and leptin concentrations in hyperandrogenic women. J Clin Endocrinol Metab 82: 3074-3077.

48. Boden G, Chen X, Kolanczynski J, Polansky M, 1997 Effects of prolonged hyperinsulinemia on serum leptin in normal human subjects J Clin Invest 100: 1107-1113.

49. Leal-Cerro A, Considine R, Peino R, Venegas E, Astorga R, Casanueva FF, Dieguez C, 1996 Serum immunoreactive-leptin levels are increased in patients with Cushing's syndrome Horm Metab Res 28: 711-713.

50. Cizza G, Lotsikas A, Licinio J, Gold P, Chrousos G, 1997 Plasma leptin levels do not change in patients with Cushing's disease shorthly after correction of hypercortisolism. J Clin Endocrinol Metab 82: 2747-2750.

51. Carro E, Senaris R, Considine R, Casanueca FF, Dieguez C, 1997 Regulation of in vivo growth hormone secretion by leptin. Endocrinology 138: 2203-2206.

52. Casanueva FF, Dieguez C, 1998 Interaction between body composition, leptin and growth hormone status. Bailliere Clin Endoc 12: 297-314.

53. Damjanovic S, Petakov M, Raicevic S, Micic D, Marinkovic J, Dieguez C, Casanueva FF, Popovic V, 2000 Serum leptin levels in patients with acromegaly before and after correction of hypersomatotropism by transsphenoidal surgery. J Clin Endocrinol Metab 85: 147-154.

54. Carro E, Seoane L, Senaris R, Casanueva FF, Dieguez C, 2000 Leptin increases in vivo GH responses to GHRH and GHRP-6 in food-deprived rats. Eur J Endocrinol 142: 66-70.

55. Lisset C, Clayton P, Shalet S, 2001 The acute leptin response to GH. J Clin Endocrinol Metab 86: 4412-4415.

56. Muller A, Janssen J, lamberts S, Bidlingmaier M, Strasburger C, Hofland L, Van der Lely AJ, 2001 Effects of fasting and pegvisomant on the $\mathrm{GH}$-releasing hormone and GH-releasing peptide-6 stimulated growth hormone secretion. Clin Endocrinol (Oxf) 55: 461-467.

57. Maccario M, Aimaretti G, Corneli G, Guana C, Grottoli S, Bidlingmaier M, Strasburger C, Dieguez C, Casanueva FF, Ghigo E, 2000 Short-term fasting abolishes the sex related difference in $\mathrm{GH}$ and leptin secretions in humans. Am J Physiol 279: 411-416.

58. Popovic V, Damjanovic S, Dieguez C, Casanueva FF, 2001 Leptin and the pituitary. Pituitary 4: 7-14.

59. Kalra S, Dube M, Pu S, Xu B, Horvath T, Kalra P, 1999 Interacting appetite-regulating pathways in the hypothalamic regulation of body weight. Endocr Rev 20: 68-100.
60. Yu W, Walczewska A, Karanth S, McCann S, 1997 Nitric oxide mediates leptin-induced luteinizing-releasing hormone secreting neurons. Endocrinology 138: 5055-5058.

61. Magni P, Vettor R, Pagano C, Calcagno C, Beretta A, Messi E, Zanisi M, Martini L, Motta M, 1999 Expression of a leptin receptor in immortalized gonadotropin-releasing hormone secreting neurons. Endocrinology 140: 15811585

62. Suter K, Pohl C, Wilson M, 2000 Circulating concentrations of nocturnal leptin, growth hormone, and insulinlike growth factor-I increase before the onset of puberty in agonadal male monkeys:potential signals for the initiation of puberty. J Clin Endocrinol Metab 85: 808-814

63. Ahima RS, Dushay J, Flier SN, Prabakaran D, Flier JS, 1997 Leptin accelerates the onset of puberty in normal female mice. J Clin Invest 99: 391-395.

64. Chehab FF, Mounzih K, Lu R, Lim ME, 1997 Early onset of reproductive function in normal female mice treated with leptin. Science 275: 88-90.

65. Cheung CC, Thornton JE, Kuijper JL, Weigle DS, Clifton DK, Steiner RA, 1997 Leptin is a metabolic gate for the onset of puberty in the female rat. Endocrinology138: 855-858.

66. Plant TM, Durrant AR, 1997 Circulating leptin does not appear to provide a signal for triggering the initiation of puberty in the male rhesus monkey (Macaca mulatta). Endocrinology 138:4505-4508.

67. Clayton PE, Gill MS, Hall CM, Tillmann V, Whatmore AJ, Price DA, 1997 Serum leptin through childhood and adolescence. Clin Endocrinol (Oxf) 46: 727-733.

68. Mantzoros CS, Flier JS, Rogol AD, 1997 A longitudinal assessment of hormonal and physical alterations during normal puberty in boys. V. Rising leptin levels may signal the onset of puberty. J Clin Endocrinol Metab 82: 10661070.

69. Garcia Mayor RV, Andrade MA, Rios M, Lage M, Dieguez C, Casanueva FF, 1997 Serum leptin levels in normal children: relationship to age, gender, body mass index, pituitary-gonadal hormones, and pubertal stage. J Clin Endocrinol Metab 82: 2849-2855.

70. Matkovic V, Ilich JZ, Skugor M, Badenhop NE, Goel P, Clairmont A, Klisovic D, Nahhas RW, Landoll JD, 1997 Leptin is inversely related to age at menarche in human females. J Clin Endocrinol Metab 82: 3239-3245.

71. Palmert M, Radovick S, Boepple P, 1998 The impact of reversible gonadal sex steroid suppression on serum leptin concentrations in children with central precocious puberty. J Clin Endocrinol Metab 83: 1091-1096.

72. Guerguiev M, Goth M, Korbotnis M, 2001 Leptin and puberty - a review. Pituitary 4: 79-86.

73. Farooqui I, Jebb S, Langmark G, Lawrence E, Cheetham C, Prentice A, Hughes I, McCamish M, O'Rahilly S, 1999 Effects of recombinant leptin therapy in a child with congenital leptin deficiency. New Engl J Med 341: 879-884.

74. Grinspoon S, Gulick T, Askari H, Landt M, Lee K, Anderson E, Ma Z, Vignati L, Bowsher R, Herzog D, Klibanski A, 1996 Serum leptin levels in women with anorexia nervosa. J Clin Endocrinol Metab 81: 3861-3863. 
75. Casanueva FF, Dieguez C, Popovic V, Peino R, Considine R, Caro J, 1997 Serum immunoreactive leptin concentrations in patients with anorexia nervosa before and after partial weight recovery. Biochem Mol Med 60: 116120.

76. Foster D, Olster D, 1985 Effect of restricted nutrition on puberty in the lamb: patterns of tonic luteinizing hormone (LH) secretion and competency of the LH surge system. Endocrinology 116: 375-381.

77. Veldhuis J, Evans W, Dengers L, Thorner M, Wakat D, Rogol A, 1985 Altered neuroendocrine regulation of gonadotropin secretion in women distance runners. J Clin Endocrinol Metab 61: 557-563.

78. Finn PD, Cunningham MJ, Pau KY, Spies HG, Clifton DK, Steiner RA, 1998 The stimulatory effect of leptin on the neuroendocrine reproductive axis of the monkey. Endocrinology 139: 4652-4662.

79. Nagatani S, Guthikonda P, Thompson RC, Tsukamura H, Maeda KI, Foster DL, 1998 Evidence for GnRH regulation by leptin: leptin administration prevents reduced pulsatile LH secretion during fasting. Neuroendocrinology 67: 370-376.

80. Ferron F, Considine RV, Peino R, Lado IG, Dieguez C, Casanueva FF, 1997 Serum leptin concentrations in patients with anorexia nervosa, bulimia nervosa and nonspecific eating disorders correlate with the body mass index but are independent of the respective disease. Clin Endocrinol (Oxf) 46: 289-293.

81. Mantzoros C, Flier JS, Lesem MD, Brewerton TD, Jimerson DC, 1997 Cerebrospinal fluid leptin in anorexia nervosa: correlation with nutritional status and potential role in resistance to weight gain. J Clin Endocrinol Metab 82: 1845-1851.

82. Laughlin GA, Yen SS, 1997 Hypoleptinemia in women athletes: absence of a diurnal rhythm with amenorrhea. J Clin Endocrinol Metab 82: 318-321.

83. Mukherjea R, Castonguay T, Douglass T, Moser Veillon P, 1999 Elevated leptin concentrations in pregnancy and lactation: possible role as a modulator of substrate utilization. Life Sci 65: 1183-1193.

84. Schubring C, Englaro P, Siebler T, Blum W, Demirakca T, Kratzsch J, Kiess W, 1998 Longitudinal analysis of maternal serum leptin levels during pregnancy at birth and up to six weeks after birthrelation to body mass index, skinfolds, sex steroids and umbilical cord blood leptin levels. Horm Res 50: 276-283.

85. Highman TJ, Friedman JE, Huston LP, Wong WW, Catalano PM, 1998 Longitudinal changes in maternal serum leptin concentrations, body composition, and resting metabolic rate in pregnancy. Am J Obstet Gynecol 178: 1010-5.

86. Lage M, Garcia-Mayor R, Tome M, Cordido F, ValleInclan F, Considine R, Caro J Dieguez C, Casanueva FF, 1999 Serum leptin levels in women throughout pregnancy and the postpartum period and in women suffering spontaneous abortion. Clin Endocrinol 50: 211-216.

87. Tamura T, Goldenberg RL, Johnston KE, Cliver SP, 1998 Serum leptin concentrations during pregnancy and their relationship to fetal growth. Obstet Gynecol 91: 389-395. 88. Gavrilova O, Barr V, Marcus Samuels B, Reitman M. 1997 Hyperleptinemia of pregnancy associated with the appearance of a circulating form of the leptin receptor. J Biol Chem 272: 30546-30551.

89. Mounzih K, Qiu J, Ewart-Toland A, Chehab F, 1998 Leptin is not necessary for gestation and parturition but regulates maternal nutrition via a leptin resistant state. Endocrinology 139: 5259-5262.

90. Masuzaki H, Ogawa Y, Sagawa N, Hosoda K, Matsumoto T, Mise H, Nishimura H, Yoshimasa Y, Tanaka I, Mori T, Nakao K, 1997 Nonadipose tissue production of leptin: leptin as a novel placenta-derived hormone in humans. Nat Med 3: 1029-1033.

91. Se@aris R, Garcia Caballero T, Casabiell X, Gallego R, Castro R, Considine RV, Dieguez C, Casanueva FF, 1997 Synthesis of leptin in human placenta. Endocrinology 138: 4501-4504.

92. Harigaya A, Nagashima K, Nako Y, Morikawa A, 1997 Relationship between concentration of serum leptin and fetal growth. J Clin Endocrinol Metab 82: 3281-3284.

93. Jaquet D, Leger J, Levy Marchal C, Oury JF, Czernichow P, 1998 Ontogeny of leptin in human fetuses and newborns: effect of intrauterine growth retardation on serum leptin concentrations. J Clin Endocrinol Metab 83: 12431246.

94. Tome MA, Lage M, Camina JP, Garcia Mayor RV, Dieguez C, Casanueva FF, 1997 Sex based differences in serum leptin concentrations from umbilical cord blood at delivery. Eur J Endocrinol 137: 655-658.

95. Matsuda J, Yokota I, Iida M, Murakami T, Naito E, Ito M, Shima K, Kuroda Y, 1997 Serum leptin concentration in cord blood: relationship to birth weight and gender. $\mathrm{J}$ Clin Endocrinol Metab 82: 1642-1644.

96. Koistinen HA, Koivisto VA, Andersson S, Karonen SL, Kontula K, Oksanen L, Teramo KA, 1997 Leptin concentration in cord blood correlates with intrauterine growth. J Clin Endocrinol Metab 82: 3328-3330.

97. Butzow TL, Moilanen JM, Lehtovirta M, Tuomi T, Hovatta O, Siecberg R, Nilsson C-G, Apter D, 1999 Serum and follicular fluid leptin during in vitro fertilization: relationship among leptin increase, body fat mass and reduced ovarian response. J Clin Endocrinol Metab 84: 3135-3139.

98. Messinis IE, Milingos S, Zikopoulos K, Kollios G, Seferiadis K, Lolis D, 1998 Leptin concentrations in the follicular phase of spontaneous cycles and cycles superovulated with follicle stimulating hormone. Human Reprod 13: 1152-1156.

99. Cioffi JA, Van Blerkom J, Antczak M, Shafer A, Wittmer S, Snodgrass HR, 1997 The expression of leptin and its receptors in pre-ovulatory human follicles. Mol Hum Reprod 3: 467-472.

100. Unkila-Kallio L, Andersson S, Koistinen H, Karonen S, Yikorkala O, Titinen A, 2001 Leptin during assisted reproductive cycles: the effect of ovarian stimulation and of very early pregnancy. Human Reprod 16: 657-662

101. Zachow R, Magoffin DA, 1997 Direct intraovarian effects 
of leptin: impairment of the synergistic action of insulinlike growth factor-I on follicle-stimulating hormone-dependent estradiol-17 beta production by rat ovarian granulosa cells. Endocrinology 138: 847-850.

102. Agarwal S, Vogel K, Magoffin D, 1997 Leptin antagonized IGF-I augmentation of FSH stimulated estradiol production in human granulosa cells. Hum Reprod 12: 68 (abstract).

103. Spicer L, Francisco C, 1997 The adipose obese gene product, leptin: evidence of a direct inhibitory role in ovarian function. Endocrinology 138: 3374-3379. 